DOI: 10.32844/2222-5374-2020-104-2.12

УДК: 342.95 (477)

Віговський C. I.,

здобувач Науково-дослідного інституту публічного права

\title{
ЩОДО МОЖЛИВОСТЕЙ СТВОРЕННЯ ЗАКОНУ УКРАЇНИ ПРО КОНТРОЛЬ ЗА ДІЯЛЬНІСТЮ СУДУ
}

Стаття присвячена формулювання пропозицій стосовно створення та прийняття у процесі поточної судово-правової реформи проєкту Закону України «Про контроль за діяльністю суду». Автором детально розкривається структура запропонованого проєкту Закону. В «Основних положеннях» пропонується визначити: поняття «контроль за діяльністю судів»; сферу застосування відповідного законопроєкту; нормативну основу та правові принципи контролю за діяльністю судів; об'єкт і предмет такого контролю; основні вимоги до здійснення контролю. Урозділі «Суб'єкти, які здійснюють контроль за діяльністю суду» законопроєкту закріплюються: перелік суб'єктів, якіздійснюють контрольза діяльністю суду; основні права та обов'язки цих суб'єктів; обов'язковість оцінювання результативності та ефективності здійснення контролю; правовий статус суб'єктів контролю, що знаходяться поза межами системи правосуддя. Розділом «Суб'єкти, щодо яких застосовуються заходи контролю за діяльністю суду» проєкту Закону пропонується визначити: коло підконтрольних суб'єктів у межах контролю за діяльністю суду; обсяг прав підконтрольних суб'єктів. У розділі «Здійснення контролю за діяльністю суду» проєкту Закону пропонується визначити: загальні підстави та умови для контролю за діяльністю судів; форми та процедури контролю; сутність та особливості профілактики ризиків відхилення підконтрольного суб'єкта від його норми діяльності. Окрема увага в законопроєкті приділяється особливостям здійснення громадського контролю за діяльністю суду, що наразі досить часто використовується в якості інструменту тиску на судову владу в Україні. У висновках до статті автором вказується на те, що прийняття проєкту Закону України «Про контроль за діяльністю суду» сприятиме нормативному закріпленню адміністративно-правових засад такого контролю, встановлюватиме рамки цієї владної діяльності, що унеможливлюватиме використання на практиці контролю в якості інструменту неправомірного тиску на судз метою спотворення правосуддя, звуження незалежності суду та самостійності суддів.

Ключові слова: діяльність місцевого суду, контроль, місцевий суд, реформа, система правосуддя, суб'єкт контролю.

Актуальність теми. Система адміністративного права України є особливим правовим утворенням, котре перебуває у постійному розвитку, «розвиваючись і ускладнюючись разом з розвитком і ускладненням суспільних відносин, які регламентуються нормами адміністративного 
права» [1, с. 10]. Однак, слід констатувати, що нормативний вираз адміністративного права не завжди є адекватним фактичній дійсності та стану наукової думки юристів-адміністративістів. У цьому сенсі відставання адміністративного права від темпів змінюваної фактичної реальності, що вимагає нових правил регулювання суспільних відносин у мінливій дійсності, свідчить про неспроможність наявних в законодавстві адміністративно-правових норм унеможливити (чи мінімізувати) проблеми в функціонуванні суб’єктів публічної адміністрації. Значним чином, в чому можна пересвідчитись аналізуючи результати адміністративно-правових реформ, «некритична, а іноді - відверто безглузда зміна законодавства, що обумовлює критичне збільшення маси норм законодавства, яка нарощує невизначеність соціального життя та його юридичних наслідків, знецінює принцип законності, загрожує пануванню права тощо» $[2$, с. 8]. У тій чи іншій мірі проблематика недостатності та надмірності регулювання контролю є характерною практично для всіх суб'єктів права, а щонайперше - для суду загалом та для місцевих судів, зокрема.

Загалом, критичний аналіз загальної характеристики контролю за діяльністю місцевих судів, а також основних адміністративно-правових засад такого контролю, вказують на численні теоретичні та практичні проблеми належного розуміння й здійснення відповідного контролю. У тій чи іншій мірі відповідні проблеми можуть бути загострені у процесі здійснення чергової судово-правової реформи, яка планується звершитись протягом 2021 року. Разом із тим, рішення про нову трансформацію системи правосуддя повинно: 1) грунтуватись на реальних проблемах діяльності судів, суддів, а також суб'єктів контролю за діяльністю судів; 2) не шкодити засадам незалежності суду та самостійності суддів; 3) засновуватись на актуальній науковій думці юристів-адміністративістів щодо відповідних перетворень у системі правосуддя. У цьому сенсі особливо актуальним постає питання вичерпного регулювання діяльності щодо контролю за діяльністю місцевих судів, що може використовуватись в якості інструменту: 1) забезпечення незалежності суду і самостійності суддів, оптимізації функціонування системи правосуддя та уможливлення оптимального захисту права на справедливий суд (коли контроль буде належним чином унормованим, а його реалізація буде відповідати вимогам ч. 2 ст. 19 Конституції України); 2) неправомірного тиску на суд $з$ метою спотворення правосуддя, звуження незалежності суду і т. д. (у тому разі, суб’єкт контролю матиме широку владу дій, обумовлену прогалинами законодавства та відсутністю спеціального законодавчого акту, що буде упорядковувати його діяльність). Особливо актуальним це питання постає у тому контексті, що в науковій літературі ученими раніше не пропонувалось прийняття спеціального закону про контроль за діяльністю місцевих судів, а законодавець наразі не планує приймати такий законодавчий акт у межах поточної судово-правової реформи.

Аналіз наукової літератури та раніше невирішені питання. Окремі пропозиції щодо вдосконалення правового регулювання здійснення контролю за діяльністю судів (зокрема, й місцевих судів) в Україні вже у тій чи іншій мірі обгрунтовувались багатьма вітчизняними науковцями, серед яких: Р. М. Аюпова, А. Л. Борко, Т. Б. Логоза, О. М. Остапенко, П. П. Порощук, 
І. Д. Прошутя, А. В. Сагун, Д. Ю. Шпенов та інші учені. Поряд із тим, слід констатувати, що на сьогоднішній день відповідні позиції юристівадміністративістів потребують актуалізації та узагальнення у вигляді комплексної пропозиції щодо створення спеціального законодавчого акту, що регулюватиме здійснення контролю за діяльністю суду в Україні.

Отже, метою цієї наукової статті $\epsilon$ формулювання пропозицій щодо створення та прийняття в процесі поточної судово-правової реформи проєкту Закону України «Про контроль за діяльністю суду». Ця мета досягатиметься шляхом виконання таких завдань: 1) окреслити основні напрями удосконалення адміністративно-правового регулювання контролю за діяльністю місцевих судів в Україні та обгрунтувати необхідність створення та прийняття проєкту Закону України про контроль за діяльністю суду; 2) запропонувати та обгрунтувати структуру такого законопроєкту; 3) узагальнити результати дослідження.

Виклад основного матеріалу дослідження. Зважаючи на актуальні проблеми здійснення контролю за діяльністю місцевих судів в Україні, а також різні пропозиції вітчизняних юристів-адміністративістів [див., напр.: 3 , с. $20-44 ; 4$, с. $401-421$; 5, с. $110-181 ; 6$, с. $13-15$; 7, с. $137-157$; 8, c. 173-187] стосовно подальшого вдосконалення діяльності місцевого суду, оптимізації контролю за діяльністю суду (також публічної служби в органах судової влади України), можемо дійти висновку про необхідність удосконалення адміністративно-правового регулювання контролю за діяльністю місцевих судів у межах таких напрямів: 1) створення та прийняття спеціального законодавчого акту, котрим комплексно врегульовуватимуться різні аспекти здійснення контролю за діяльністю судів загалом та місцевих судів, зокрема; 2) створення та прийняття проєкту закону, яким буде унеможливлено створення державою фінансових умов, які становлять собою бар'єр для належного функціонування суду, а також відновлено діяльність Вищої кваліфікаційної комісії суддів України (далі - ВККСУ) та встановлено нормативні застереження, що унеможливлюють виникнення ситуацій з блокування діяльності Комісії у майбутньому; 3) створення та прийняття уніфікованого підзаконного акту, в якому будуть міститись типові порядки та методики здійснення контролю за діяльністю судів.

Серед окреслених напрямів удосконалення законодавства особливе місце посідає створення та прийняття проєкту Закону України про контроль за діяльністю суду. Вказане можна пояснити тим фактом, що удосконалення контролю за діяльністю судів $\epsilon$ частиною адміністративної реформи, ефективність правового забезпечення якої, на думку вітчизняного юристаадміністративіста М. М. Тернущака, «прямо залежить від якості законотворчого процесу та $є$ таким, що потребує поглибленого аналізу, з огляду на політику держави щодо удосконалення практик публічного адміністрування, відправлення судівництва та боротьби з корупцією» [9, с. 316-317]. Виходячи із цієї позиції науковця, а також з проблеми відсутності законодавчого акту, яким регулюється контроль за діяльністю суду, вбачається доцільність у розробленні та прийнятті вказаного проєкту Закону, що буде містити такі структурні частини:

1) «Основні положення». У межах цієї частини проєкту Закону доцільно забезпечити юридичну визначеність: 
а) явища «контроль за діяльністю судів», особливим виявом якого $€$ досліджуваний нами контроль за діяльністю місцевих судів. Зазначене може бути реалізоване шляхом закріплення у пропонованому законопроєкті «Про контроль за діяльністю суду» статті 1 «Контроль за діяльністю судів», в якому буде міститись загальне визначення цього явища (ч. 1), а також конкретизуватиметься сутнісне спрямування такого контролю (ч. 2). Окреслюючи спрямованість відповідної адміністративно-правової діяльності слід мати на увазі, що ця діяльність має бути спрямована на досягнення суспільно значущих результатів, пов'язаних з мінімізацією ризику заподіяння шкоди (збитків) охоронюваним законом цінностям, викликаних неналежною діяльністю суду, структурних підрозділів суду, посадових осіб та інших працівників суду;

б) сфери застосування відповідного законопроєкту, а саме шляхом закріплення у пропонованому проєкті Закону статті 2 «Сфера застосування закону», в якій слід зазначити, що відповідний законодавчий акту повинен поширювати свою дію на суспільні відносини, пов'язані із організацією та здійсненням контролю за діяльністю суду, встановлюючи при цьому гарантії захисту прав суб'єктів такого контролю. Крім того, доцільним вбачається також закріпити у цій статті й застереження про те, що цей Закон не може бути застосованим у процесі здійснення контролю за здійсненням правосуддя;

в) нормативної бази та принципів контролю за діяльністю судів загалом та місцевих судів, зокрема;

г) об’єкта та предмета контролю за діяльністю місцевих судів шляхом закріплення у пропонованому законопроєкті відповідних статей, в яких має бути окреслено переліки об'єктів і предметів цього контролю;

г) вимог до здійснення контролю за діяльністю судів шляхом закріплення у пропонованому проєкті Закону статті 7 «Загальні вимоги до здійснення контролю за діяльністю судів», в якому слід закріпити правило, згідно якого контроль повинен здійснюватися повноважним суб'єктом виключно за наявності достатніх підстав і умов, визначенихузаконодавстві. Крім того, важливим застереженням, яке доцільно передбачити в законодавстві $\epsilon$ заборона здійснення контролю за діяльністю місцевих судів: різними суб'єктами з одного й того самого питання; посадовою особою суб'єкта контролю щодо працівника суду, з яким вона перебуває у родинних стосунках, або ж в разі виникнення у неї конфлікту інтересів у сенсі антикорупційного законодавства;

2) «Суб'єкти, які здійснюють контроль за діяльністю суду». У межах цієї структурної частини пропонованого проєкту Закону необхідно вирішити такі питання здійснення досліджуваного контролю:

а) окреслити перелік суб'єктів, які повноважні здійснювати контроль за діяльністю місцевих судів, враховуючи їх поділ на: суб’єктів системи правосуддя, що здійснюють внутрішній контроль за діяльністю місцевих судів (суб'єкти рівня безпосереднього самоконтролю; суб'єкти рівня відносного самоконтролю); суб'єкти здійснення контролю за діяльністю місцевих судів, які знаходяться поза системою правосуддя (суб'єкти рівня безпосереднього контролю; суб'єкти рівня опосередкованого контролю); 
б) визначити основні права та обов'язки суб'єктів контролю за діяльністю місцевих судів, а також уточнити перелік обмежень і заборон, пов'язаних із виконанням повноважень суб'єктом, який здійснює контроль за діяльністю місцевих судів;

в) закріпити обов'язковість оцінювання результативності та ефективності здійснення контролю за діяльністю місцевого суду, а саме шляхом викладення у пропонованому проєкті Закону загальної статті 10, в якій встановлюватиметься правило, згідно якого відповідне оцінювання повинно здійснюватися за кожним видом контролю в порядку та на основі системи показників результативності й ефективності контролю за діяльністю суду, визначених пропонованим законопроєктом, а також базовою моделлю результативності та ефективності контрольно-наглядової діяльності суб'єктів контролю (має бути розроблена та затверджена Вищою радою правосуддя), іншими актами, прийнятими на виконання пропонованого Закону. Систему показників результативності та ефективності діяльності суб'єктів контролю повинні складати ключові та індикативні показники контролю за діяльністю суду. При цьому ключовими такими показниками будуть ті, що відображають: рівень мінімізації міри відхилення та запобігання можливому відхиленню діяльності суду від стандартів його діяльності на всіх рівнях функціонування структурних підрозділів суду, діяльності працівників суду; рівень ефективності впливу на діяльність підконтрольних суб'єктів, вираженого у забезпеченні належної діяльності суду. Закономірним чином вказану пропозицію слід доповнити застереженням, у відповідності до якого неприпустимим є встановлення ключових показників на основі кількісних показників: проведених контрольних заходів, здійснених контрольних дій; виявлених відхилень діяльності суду від стандартів його діяльності; працівників суду, притягнутих до дисциплінарної та/або матеріальної відповідальності. Що ж стосується зазначених індикативних показників контролю, то такими є показники, застосовні для: моніторингу та аналізу контрольної діяльності; виявлення проблем, які виникають при здійсненні контрольної діяльності, а також визначення причин виникнення таких проблем; встановлення рівня правомірного та неправомірного втручання в діяльність контрольованих осіб.

У цій статті також необхідно визначити розробників проєкту ключових і індикативних показників контролю (ВККСУ, Рада суддів України та Державна судова адміністрація України), особливості його затвердження ВРП, а також обов'язок суб'єктів контролю здійснювати підготовку звіту про контрольну діяльність та оприлюднювати ці звіти кожні півроку. У вказаних звітах повинні міститись вичерпні відомості про організацію та проведення контролю за діяльністю суду на відповідному рівні здійснення суб'єктом такого контролю, а саме у межах таких складових частин цього звіту: стан нормативно-правової бази діяльності суду та контролю за діяльністю суду; організація контролю за діяльністю суду; кадрове та фінансове забезпечення контролю за діяльністю суду; проведення контролю за діяльністю суду; дії суб’єктів контролю, спрямовані на запобігання відхиленню діяльності суду від норми діяльності; дії суб'єктів контролю, спрямовані на виявлення та усунення недоліків діяльності 
суду; аналіз і оцінка ефективності здійсненого контролю за діяльністю суду; висновки та пропозиції за результатами здійсненого контролю за діяльністю суду. Крім того, доцільно закріпити також правило, у відповідності до якого на основі опублікованих даних піврічних звітів про контроль за діяльністю суду ВРП повинна складати зведену доповідь, що публікується на її офіційному веб-сайті не пізніше 15 квітня та 15 вересня. Між тим, зважаючи на те, що результати контролю за діяльністю місцевого суду досить часто не враховуються у процесі вдосконалення правового регулювання діяльності місцевого суду та контролю за діяльністю суду (це є одним з чинників, який обумовлює формалізм такого контролю), слід в законодавстві також закріпити норму, у відповідності до якої висновки і пропозиції у зведеній доповіді ВРП повинні бути основою, з огляду на яку парламентський комітет з питань правової політики повинен готувати проєкт Закону України про вдосконалення правового режиму діяльності суду та контролю за діяльністю суду;

г) уточнення правового статусу суб'єктів контролю, котрі знаходяться поза межами системи правосуддя (парламенту, Президента України, Уповноваженого ВР України з прав людини, Національного агентства 3 питань запобігання корупції, Національного агентства України з питань державної служби), шляхом закріплення у пропонованому законопроєкті окремої статті, в якій буде встановлюватись застереження, що відповідні контрольні функції цих суб'єктів здійснюються у відповідності до Конституції України, з урахуванням положень цього Закону та без шкоди незалежності суду і самостійності суддів;

3) «Суб'єкти, щодо яких застосовуються заходи контролю за діяльністю суду», що є структурних підрозділом, котрим врегульовуються такі питання:

а) окреслення переліку суб'єктів, які вважаються підконтрольними суб'єктами у контексті здійснення контролю за діяльністю місцевих судів, а саме шляхом віднесення до цих суб’єктів: місцевого суду, як юридичної особи публічного права; апарату суду та інших структурних підрозділів суду; голови суду та його заступників; суддів; керівників апарату суду та його заступників; працівників апарату суду; помічників суддів патронатної служби;

б) визначення обсягу основних прав підконтрольних суб'єктів, зокрема: бути поінформованим про свої права та обов'язки, гарантії захисту своїх прав; перевіряти наявність у контролюючого суб'єкта повноважень на здійснення контролю та отримувати інформацію про підстави та умови, на основі яких здійснюється контроль; протягом проведення контролю отримувати від суб'єкта контролю інформацію, що відноситься до об'єкта та предмета заходів контролю, контрольних дій, якщо інше не передбачено законодавством; вимагати припинення контролю у разі перевищення суб'єктом контролю власних повноважень або зловживання цими повноваженнями; оскаржувати в установленому законом порядку неправомірні дії суб'єктів контролю і т. д.;

4) «Здійснення контролю за діяльністю суду», що $є$ структурним елементом пропонованого проєкту Закону, у межах якого врегульовуються такі питання: 
а) загальні підстави та умови для контролю за діяльністю судів, а саме шляхом закріплення у статті 15 законопроєкту правило, у відповідності до якого зазначений контроль повинен здійснюватися компетентним суб'єктом у межах повноважень з питань, визначених законодавством, на підставі норми закону та в ситуаціях, виникнення яких потребує здійснення контролю за діяльністю суду;

б) форми (розвідувально-діагностичні; запобіжні та мобілізаційні; коригуючі; звітні) та процедури (безпосереднього та опосередкованого) контролю за діяльністю місцевих судів;

в) сутність та особливості профілактики ризиків відхилення підконтрольного суб'єкта від його норми діяльності. У статті 18 законопроєкту доцільно визначити цілі такої профілактики. Відповідними цілями, на нашу думку, є: по-перше, формування сприятливих умов діяльності суду та стимулювання дисциплінованого і сумлінного дотримання підконтрольними суб'єктами комплексу обов'язкових вимог, яких вони повинні дотримуватись; по-друге, усунення виявлених факторів, які створюють умови для неналежної діяльності суду;

5) «Особливості здійснення громадського контролю за діяльністю суду». 3 огляду на те, що сьогодні т. зв. «демократичний контроль» за діяльністю місцевих та інших судів досить часто перетворюється на інструмент тиску на суд, в межах статті 19 проєкту Закону доцільно закріпити правило, що такий вид контролю є обмеженим і виявляється у: запитуванні та зборі інформації про непроцесуальну діяльність суду, структурних підрозділів суду, працівників суду; зверненні до інших повноважних суб'єктів контролю за діяльністю місцевих судів із зверненнями (скаргами), в яких повідомляються факти про неправомірні дії працівників суду.

Висновки. Ефективність діяльності суду в Україні може бути досягнута в тому разі, коли в державі у належній мірі буде функціонувати механізм забезпечення діяльності суду (правового, кадрового, матеріально-технічного, фінансового забезпечення), а діяльність суду буде підлягати збалансованому контролю, що не уособлюватиме інструмент впливу на здійснення в країні правосуддя. Вказаного стану діяльності суду та суб'єктів контролю за діяльністю суду можна досягти у процесі здійснення триваючої судово-правової реформи в Україні, а саме тоді, коли в рамках відповідних чергових трансформацій законодавцем буде приділена достатня увага питанням вдосконалення правового режиму контролю за діяльністю судів. Комплексним чином це завдання може буде виконане у тому разі, коли законодавчі ініціативи виконавчої влади наразі будуть стосуватись щонайперше забезпечення належного функціонування місцевих судів, а також суб'єктів контролю за цими судами. У цьому контексті потребується створення та прийняття пропонованого нами проєкту Закону України «Про контроль за діяльністю суду», що міститиме основні адміністративно-правові засади здійснення такого контролю й не припускатиме використання такої адміністративноправової діяльності для звуження незалежності суду та самостійності суддів в Україні. 


\section{СПИСОК ВИКОРИСТАНИХ ДЖЕРЕЛ}

1. Мельник Р. С. Новели сучасної концепції українського адміністративного права. Lex portus. 2017. № 5 (7). С. 5-16.

2. Гладкий В. В. Мінливість і занепад законодавства: постановка питання. Актуальні проблеми реформування сучасного законодавства: матер. III міжнар. наук.-практ. конф. (м. Харків, 14-15 верес. 2018 р.). Херсон: Гельветика, 2018. С. 5-10.

3. Гірський Б. О.Адміністративно-правове забезпечення управлінської діяльності голови суду: дис. ... канд. юрид. наук: 12.00.07. Тернопіль, 2020. 205 c.

4. Голобутовський Р. 3. Адміністративно-правові засади публічної служби в органах судової влади в Україні: дис. ... д-ра юрид. наук: 12.00.07. Запоріжжя, 2020. 485 с.

5. Кравчик М. Б. Реформування судової системи як важлива складова європейської інтеграції України: дис. ... канд. юрид. наук: 12.00.10. Львів, 2015. 217 c.

6. Крусян Р. А. Реформування системи судоустрою України: досвід, сучасність, тенденції: автореф. дис. ... канд. юрид. наук. 12.00.10. Київ, 2018. $24 \mathrm{c}$.

7. Мащук В. Ю. Адміністративно-правове забезпечення функціонування апаратів судів загальної юрисдикції: дис. ... канд. юрид. наук: 12.00.07. Дніпропетровськ, 2014. 218 с.

8. Шпенова П. Ю. Апарат суду в системі організаційного забезпечення судової діяльності: дис. ... канд. юрид. наук: 12.00.07. Харків, 2019. 224 с.

9. Тернущак М. М. Адміністративний процес у публічному адмініструванні: дис. ... д-ра юрид. наук: 12.00.07. Київ, 2020. 401 с.

\section{S. Vihovskyi}

\section{ON THE POSSIBILITIES OF CREATING THE LAW OF UKRAINE ON CONTROL OF COURT ACTIVITIES}

The article focuses on the formulation of proposals for the creation and adoption of the draft Law of Ukraine "On control over the activities of the court" in the process of the current judicial and legal reform. The author reveals in detail the structure of the proposed draft Law. In the "Basic Provisions" it is proposed to define: the concept of "control over the activities of courts"; the scope of the relevant draft law application; regulatory framework and legal principles of control over the courts activities; object and subject of such control; basic requirements for control. The section "Subjects exercising control over the court activities" provides the draft law with: a list of subjects that exercise control over the activities of the court; the basic rights and obligations of these subjects; the obligation to assess the effectiveness and efficiency of control; the legal status of the subjects of control that are outside the justice system. The section "Subjects to which measures of control over the court activities are applied" to the draft Law is proposed to determine: the range of controlled entities within the framework of control over the activities of the court; the scope of the rights of controlled entities. In the section "Exercising control over the activities of the court", the draft Law is proposed to determine: 
general grounds and conditions for control over the activities of courts; forms and procedures of control; the essence and features of preventing the risks of deviation of the controlled entity from its normal activity. Particular attention in the draft law is paid to the peculiarities of public control over the court activities, while it is quite often used as a tool to put pressure on the judiciary in Ukraine. In the conclusions to the article, the author points out that the adoption of the draft Law of Ukraine "On control over the activities of the court" will contribute to the normative consolidation of the administrative and legal basis of such control, establishing the boundaries of this power activity, which make it impossible to use control in practice as an instrument of undue pressure on court for the purpose of distorting justice, narrowing the independence of the court and the judges' autonomy.

Keywords: control, justice system, local court activities, local court, reform, subject of control. 